\title{
Erratum to: 'Identification of candidate gonadal sex differentiation genes in the chicken embryo using RNA-seq'
}

Katie L. Ayers ${ }^{1,2}$, Luke S. Lambeth ${ }^{1}$, Nadia M. Davidson ${ }^{1}$, Andrew H. Sinclair ${ }^{1,2}$, Alicia Oshlack ${ }^{1}$ and Craig A. Smith ${ }^{3^{*}}$

Unfortunately, the original version of this article [1] contained an error in Figure 2. The correct figure is included below:

* Correspondence: craig.smith@monash.edu

${ }^{3}$ Department of Anatomy and Developmental Biology, Monash University,

Clayton, VIC 3168, Australia

Full list of author information is available at the end of the article 


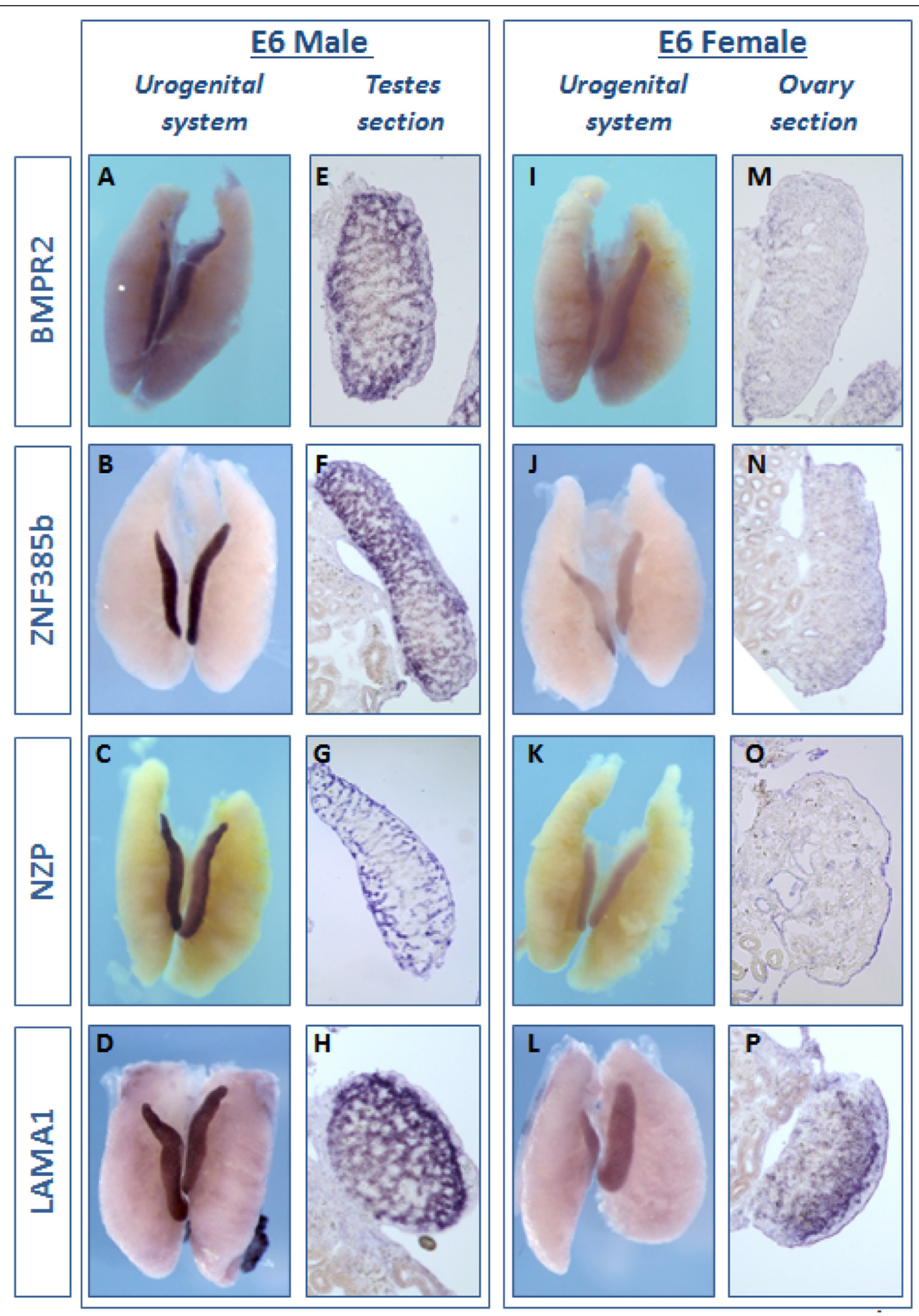

Fig. 2 (See legend on next page.) 
(See figure on previous page.)

Fig. 2 Male candidate gene expression in vivo. Whole mount in situ hybridisation for 4 male-biased candidate genes, on E6 UGS (UGS) from males and females. BMPR2 is more highly expressed in males $(\mathbf{a}, \mathbf{e})$ than in females $(\mathbf{i}, \mathbf{m})$. In over-stained sections, BMPR2 appears to be expressed in the testis cords (e). ZNF385b shows greater expression in males $(\mathbf{b}, \mathbf{f})$ than females $(\mathbf{j}, \mathbf{n})$, consistent with RNA-seq. In males it is expressed in the cords (f). NZP, a novel Z-protein, is expressed in males more highly than females (c, $\mathbf{g}$ versus $\mathbf{k}, \mathbf{o})$. It is also expressed in the cords of males ( $\mathbf{g}$ ). LAMA1 is also higher in males (d) than females (I) and is expressed in testis cords in males (h), with some weak expression in the juxta-cortical medulla in females (p). These results are consistent with RNA-seq data. Typically, 3 UGS from each sex were used for each probe, and these images are representative. A sense control probe did not show any staining for any of the candidate genes (data not shown)

\section{Author details}

${ }^{1}$ Murdoch Childrens Research Institute, Royal Children's Hospital, Flemington Road, 3052 Parkville, VIC, Australia. ${ }^{2}$ Department of Paediatrics, University of Melbourne, Parkville, VIC, Australia. ${ }^{3}$ Department of Anatomy and

Developmental Biology, Monash University, Clayton, VIC 3168, Australia.

\section{Published online: 02 March 2016}

\section{Reference}

1. Ayers KL, Lambeth $L S$, Davidson NM. Identification of candidate gonadal sex differentiation genes in the chicken embryo using RNA-seq'. BMC Genomics. 2015:16:704.

Submit your next manuscript to BioMed Central and we will help you at every step:

- We accept pre-submission inquiries

- Our selector tool helps you to find the most relevant journal

- We provide round the clock customer support

- Convenient online submission

- Thorough peer review

- Inclusion in PubMed and all major indexing services

- Maximum visibility for your research

Submit your manuscript at www.biomedcentral.com/submit
C Biomed Central 